Hassan, Amna

PhD Student

PTE ÁJK
DOI: 10.15170/DIKE.2020.04.01.13

\title{
The Shariah Law in Pakistani Legal System and General Legal Status of Women in Pakistan
}

This paper puts emphasizes on the prevailing Shariah law, along with the common law system, in Pakistan and its impact on the status of women residing in Pakistan. In the beginning, the chapter opens up with the prime focus on elaborating the concept, origin and historical background of Shariah law. As Shariah law is commonly referred to as the Islamic law or Islamic Jurisprudence, it is related to the teachings of the Holy Quran and Sunnah of the Prophet (PBUH) and this paper seeks to address specifically those teaching of the Shariah that are related to Muslim women. The paper then chalks out in detail the historical background of Shariah law system in Pakistan, since independence to date. Moving on, the paper then focuses on analyzing the status of women in Pakistan through the lens of prevailing Shariah law system. The status of women is analyzed on two basic parameters, that is, on the basis of their rights provided under Shariah law and on the basis of their rights under constitutional and other legal statues in Pakistan. In the end, the chapter concludes with comprehensive essence of the entire topic.

Keywords: Shariah law, Pakistani legal system, status of women, rights of women

\section{Introduction}

The Shariah law (also known as Islamic law) has been in existence since long, even before the establishment of Islamic states in the $18^{\text {th }}$ and $19^{\text {th }}$ centuries, along with some other cultural norms. ${ }^{1}$ Traditionally, Shariah law was construed by independent muftis (commonly referred to as jurists), based on the teachings of Islam and various legal sources. However, at present, these Shariah laws have been replaced by European statutes or codes in majority Muslim countries, while retaining the classical rules of Shariah under the realm of family laws. ${ }^{2}$ The legislative bodies in the Muslim countries aimed at codifying the rules of Shariah in an attempt to modernize them with the changing needs of the hour, without abandoning their basis in traditional jurisprudence. In the $20^{\text {th }}$ century, Islamist movements called for the complete implementation and enforcement of Shariah law, together with hudood punishments e.g. stoning to death. ${ }^{3}$ There are certain Muslim minority countries, in addition to Muslim majority countries, that enforce Shariah laws in matters relating to personal status like marriage, divorce, inheritance, property etc.

To define, Shariah law is a fundamental religious law that forms the core of Islamic tradition. According to the long-standing theory of Islamic Jurisprudence, there exist four fundamental sources of Shariah law, namely the Holy Quran, Sunnah (acts and sayings of the

\footnotetext{
${ }^{1}$ OTTO, Shariah Incorporated 615-616.

${ }^{2}$ OTTO, Shariah Incorporated 19.

${ }^{3}$ MAYER, Law: Modern Legal Reform 381-389.
} 
Prophet), Ijma (juridical consensus) and Qiyas (analogical reasoning). ${ }^{4}$ Several schools of thought in Islam, (including Hanafi, Maliki, Shafi'i, Hanbali and Jafari) developed their legal methodologies in accordance with the teachings of these four basic sources of Islamic law. The traditional jurisprudence, referred to as fiqh under Shariah law, makes a distinction between two fundamental branches of Shariah law into ibadat (rituals) and muamalat (social relations). This distinction gives rise to a variety of topics, which leads to an overlapping of certain Shariah law notions with that of the Western law, whereas certain Shariah law issues remain intact emphasizing on the need to live in accordance with the teachings of All-Mighty Allah.

The figh was expounded through the help of religious scholars, mostly by way of legal opinions (also known as fatwas) issued by expert jurists. Historically, fiqh was enforced in the Shariah courts by a judge, who was appointed by the ruler of that time. It was the duty of the judge to settle issues relating to civil disputes and societal matters. While criminal justice was ensured and administered by the sultanic courts, police, and market inspectors, who were given the discretion to decide such matters either in accordance with the Shariah law or state law. The minority communities (usually non-Muslims) enjoined the legal independence in matters pertaining to personal status, where Shariah law was no longer applied and they were given autonomy to seek justice in the light of their own religion. It took centuries for the Sunni jurists to acquire a credible position in the state bureaucracies, thus struggling to complement the laws enacted by Muslim rulers related to economics, criminal and administrative law. The very first sign of their struggle was witnessed in the Ottoman Civil Code (1869-1876), where these jurists sought to codify and incorporate the Shariah law in the state law. ${ }^{5}$

Nevertheless, at present, several Statutes based on European models are in regulation in most of the Muslim countries attempting to replace the classical Shariah laws. ${ }^{6}$ Not only this, the Muslim countries also brought their legal education and judicial practices in accordance with the European practice. Although most of the Muslim countries still hold onto the notions of Shariah law in their constitutions, yet those classical notions of Shariah law have been strictly specified to the family laws or personal status laws. The legislative bodies in the Muslim countries aimed at codifying the rules of Shariah in an attempt to modernize them with the changing needs of the hour, without abandoning their basis in traditional jurisprudence. ${ }^{7}$ In the $20^{\text {th }}$ century, Islamist movements called for the complete implementation and enforcement of Shariah law, together with hudood punishments e.g. stoning to death. In certain cases, this Islamization led to classical legal reform, whilst in other cases some progressive reformers advocated for the reinterpretation of Shariah by the qualified judiciary. Although these budood punishments are held with symbolic importance in seeking international attention, the Muslim countries are seen reluctant in enforcing these budood punishments in their territories and their implementation is based in accordance with the political climate of the country. ${ }^{8}$

There are several instances where non-Muslim countries allow for the use of Shariah law for their Muslim-minority in matters of personal status. ${ }^{9}$ While there some other non-Muslim

\footnotetext{
${ }^{4}$ Esposito - DeLong-Bas, Women in Muslim family law 2.

${ }^{5}$ MAYER, Law: Modern Legal Reform 381-389.

${ }^{6}$ OTTO, Shariah and National Law in Muslim Countries 19.

${ }^{7}$ MAYER, Law: Modern Legal Reform 381-389.

${ }^{8}$ OTTO, Shariah and National Law in Muslim Countries 20.

${ }^{9}$ STAHNKE - BLITT, The Religion-State Relationship and the Right to Freedom of Religion or Belief 13-19.
} 
countries where their significant Muslim minority has made several calls for adoption of Shariah law in the legal system and these calls have become the hot issues of international debate. In addition, several Islamic movements in the Muslim-majority countries have called for re-instating Shariah law in the legal system referring to their demand as 'a longstanding goal for Islamist movements', and such calls for re-instating or expanding Shariah law accompanied with controversy, violence, and even warfare.

\section{Historical background of Shariah law in Pakistan}

Pakistan bears a mixed legal system, that is, a combination of Shariah law and common law. When Pakistan got independence in 1947, English laws remained in force until a new constitution was chalked-out. The founder and father of Pakistan - Mubammad Ali Jinnah envisaged a legal system for Pakistan in complete compliance or consonance with the teachings of Islam, which could not come true during his life. But his vision was long carried on and bore lasting impact on the lawmakers in Pakistan in later times. The regime of General Zia-ul-Haq bears witness to Jinnab's vision, as Shariah law was incorporated into the Constitution of Pakistan, paving way for Islamization process in the country. ${ }^{10}$

Nevertheless, Jinnah was successful in formulating the political ideology of the country. During the time of his stay at Lincoln's Inn for studying law, Jinnah found British liberalism attractive and appealing. This ideal of British liberalism appealed him so much so that he adopted the English common law into Pakistani legal system upon its independence. He assumed for himself the role of ceremonial figurehead of Pakistani politics and therefore, Pakistan became a common law system country, possessing adversarial court procedure and other common law practices like judicial precedent and the idea of stare decisis. However, there are considerable differences in Pakistani common law system with that of the traditional one. Firstly, the laws in Pakistan are entirely codified, be they civil or criminal laws. This is due to the enactment of Statutes by the British during their rule in the subcontinent. Secondly, the ideal of jury trials no longer exists in Pakistani common law due to dissatisfaction in its operation and mistrust from both the judiciary and public. One Pakistani judge is reported calling these jury trials as 'amateur justice'. Thirdly, Pakistani jurisprudence is by-and-large influenced from the US-style federal structure with regards to its constitution. Fourthly, Shariah law along with the traditional jirga system bears influence in the judicial development of the country.

Keeping in view Jinnah's vision of an Islamic state, the ulama or Islamic clergy got in near association with Jinnah and acquired strength. After Jinnah's demise (just one-year after independence), one of the ulama's namely Maulana Shabbir Ahmad Usmani portrayed Jinnah as the greatest Muslim after the Mughal Emperor Aurangzeb and also compared his death to the demise of Prophet (PBUH). Maulana asked the entire nation to memorize Jinnah's message related to 'Unity, Faith and Discipline' and to work in the direction of fulfilling his dream: Jinnah wanted to create a solid bloc of all Muslim states from Karachi to Ankara, from Pakistan to Morocco. He wanted to see the

\footnotetext{
${ }^{10}$ SAIGOL, Pakistan's Long March 208-210.
} 
Muslims of the world united under the banner of Islam as an effective check against the aggressive designs of their enemies.'11

The initial steps to transform the country into the desired Islamic state, as postulated by Jinnah, were taken by the very first prime minister of Pakistan - Liaquat Ali Khan. He presented before Objectives Resolution before the Constituent Assembly in 1949, which clearly gave the entire sovereignty in the universe to Allah Almighty. Not only this, the then president of the leading political party (Muslim League) in Pakistan shared his intentions of bringing together the entire Muslim nations in the world into one entity, i.e. pan-Islamic entity. ${ }^{12}$ One of the initial researchers on Pakistani politics, Keith Callard also witnessed the essential faith of Pakistanis in the power of unity among the Muslim nations, stating: 'Pakistan was founded to advance the cause of Muslims. Other Muslims might have been expected to be sympathetic, even enthusiastic. But this assumed that other Muslim states would take the same view of the relation between religion and nationality.'.

However, this pan-Islamic approach was not received in the same context by other Muslim nations at that time, due to the simple reason of the origin and basis of development of such nations. In many Muslim nations, the ideals of nationalism arose based not only on Islam but also on other essential factors like the ethnicity, language and culture. Such Muslim nations were against this pan-Islamic approach of Pakistan as they weighed other essential factors more than the religion. Besides their opposition, however, a large number of Islamists were attracted towards Pakistan based on its pan-Islamic approach, including figures like the Grand Mufti of Palestine, Al-Hajj Amin al-Husseini, and leaders of Islamist movements, e.g. the Muslim Brotherhood. ${ }^{14}$

As Pakistan was, from the beginning separated into two wings, East and West Pakistan. The East Pakistanis were suffering enormously at the hands of the minority West Pakistan wing. Therefore, in 1971, the East wing finally got independence from the West wing and became a new country (now known as Bangladesh). As a result of the elections already held in 1971, the Pakistan People's Party (PPP) won the elections and became the first elected government of West Pakistan (now known as the Islamic Republic of Pakistan) in years from 1947. This party was successful in constituting a legislative body capable of bringing a landmark constitution in the country in $1973,{ }^{15}$ known as the Constitution of 1973 . Under this Constitution, the country was declared to be an Islamic Republic that is Islam became the state religion. It also declared that the entire laws in force in the country be brought in accordance with the teachings of Islam as enshrined in the Holy Quran and Sunnah of the Prophet (PBUH). It further stated that no law in derogation of the Islamic teachings is to be enforced in the country. ${ }^{16}$ For that purpose, several institutions were established in country, for instance the Shariah Court and Council of Islamic Ideology $(\mathrm{CII})^{17}$.

\footnotetext{
11 DhuliPAla, Epilogue. In: Creating a New Medina: State Power, Islam, and the Quest for Pakistan in Late Colonial North India 462-495.

${ }^{12}$ LAPIDUS, A history of Islamic societies 382-384.

13 SAIGOL, Pakistan's Long March 208-210.

${ }^{14}$ Dhulipala, Creating a New Medina 489.

${ }^{15}$ HaQQANI, Pakistan: Between Mosque and Military 18.

${ }^{16}$ SAIGOL, Pakistan's Long March 491.

${ }^{17}$ Dhulipala, Creating a New Medina 19.
} 
On July $5^{\text {th }}, 1977$, the government of PpP was overthrown by a military coup led by the then Army General Zia-ul-Haq..$^{18}$ About two years before the government of PPP was overthrown by this military coup, the party had to face vigorous opposition from the Islamic revivalist united under the banner of Nizam-e-Mustafa (meaning the 'Rule of the Prophet'). These Islamic revivalists believed in the establishment of Pakistan in accordance with the laws of Shariah in totality. That meant a return to the system of justice and rule of the like in the days of the Prophet (PBUH). ${ }^{19}$ In an attempt to support this wave of Islamization, the PpP prime minister, Zulifqar Ali Bhutto banned several vices against Islamic teachings including wine drinking or selling by Muslims or in nightclubs or during horse racing etc. ${ }^{20}$

However, when Zia took over Bhutto's government, the centerpiece ${ }^{21}$ of his governmental policy $^{22}$ was Islam and Islamization. He committed himself onto establishing Pakistan into an Islamic state by enforcing the Shariah law. He established a parallel court system by forming the basis of Shariah courts and separate court benches ${ }^{23}$ to decide legal cases by employing Islamic doctrines. ${ }^{24} \mathrm{He}$ also added several new criminal punishments and offences to the existing criminal law of the country, including the offences of adultery, fornication, and blasphemy to be punished by whipping, amputation, or stoning to death etc. The concept of 'interest' was replaced with that of 'profit and loss' for the purposes of bank accounts and an annual 2.5\% of tax was imposed on bank accounts for the purposes of Zakat donations. The syllabus of academic institutes along with the libraries was reviewed to remove any un-Islamic material. ${ }^{25}$ All the institutes including offices, schools, and factories were asked to provide facility and space for prayer in their territory. He also bolstered the impact of ulama's and Islamic political parties, through which these conservative scholars became regular television figures. ${ }^{26}$ Not just this, he also instated around ten-thousand Jama'at-i-Islami activists in the government posts to make certain that his Islamization struggles would continue even after his demise. ${ }^{27}$ The Council of Islamic Ideology was recruited with majority conservative ulama's. He also established separate electorates for the minorities in the country, for instance the Hindus and Christians in 1985, besides the dissatisfaction of minorities with such decision. ${ }^{28}$

Until Zia came into power, the Islamic revivalists had no real force in the country. But upon his arrival, they changed the entire foundation of Pakistan's legal history. Zia played pivotal role in the move towards Islamization possibly due to his personal piety ${ }^{29}$ and desire to acquire political stronghold. ${ }^{30}$

\footnotetext{
${ }^{18}$ KHAN, Global connections 2016.

${ }^{19}$ DiAmANTIDES - GEAREY, Islam, Law and Identity 196.

${ }^{20}$ IQBAL, The Right to Development in International Law 189.

${ }^{21}$ Grote, Constitutionalism in Islamic Countries 196.

${ }^{22}$ Dhulipala, Creating a New Medina 198.

${ }^{23}$ KEPEL, Jihad: The Trail of Political Islam 100-101.

${ }^{24}$ HeNG - LIEW, State and Secularism: Perspectives from Asia 360.

${ }^{25}$ HAQQANI, Pakistan: Between Mosque and Military 395.

${ }^{26}$ JONES, Pakistan: Eye of the storm 16, 17.

${ }^{27}$ Human Rights Watch, Double Jeopardy 19.

${ }^{28}$ WYNBRANDT, A Brief History of Pakistan 216-217.

${ }^{29}$ TALBOT, Pakistan, a Modern History 251.

${ }^{30}$ LONG - SINGH - SAMAD - TALBOT, State and Nation-Building in Pakistan 167.
} 


\section{General legal status of women in Pakistan}

Sadly, women have been in a difficult situation, faced with the miserable mindset of their opposite sex which has influenced the whole of human history. Women was used and abused in every culture to satisfy the desires of men whether they be Greek, Roman, Persian and Arab cultures where the afore-mentioned gender was treated as a means of pleasure, offered to other hands for a negligible sum and buried alive. In addition, it is regrettable to state that women have spent a very unhappy life because they have not been granted basic rights to live with their own desire, to speak out against the oppression of their men who have wrought cruelty against them and to cast their vote and contest elections by confining them within the four walls of the house. Also in the view of certain esteemed and revered thinkers who are considered to be the founders of their domains, they made protracted and unremitting attempts to change the universe, offering plenty of political philosophies, such as Plato, Aristotle, Machiavelli, Thomas Hobbes, John Locke and Rousseau, stating that women are incapable of heading any country and becoming heads of state. ${ }^{31}$

Therefore, in the Indian mail patriarchal culture, women still had no human rights; the freedom to live with their own interests, the right to express and the right to vote, and they were considered as animals because of the principle of Sati in which women were stripped of the right to live after their husbands had died. Furthermore, Pakistani community is still patriarchal and transformed society dominated by mail chauvinism where the role of a woman is not remarkable while her counterpart receives all freedoms in all walks of life, neglecting more than $50 \%$ of the female gender population. Particularly in rural areas women's lives are very sad, depicting a boring image in which they are forced to bear their husbands' cruel disposition of anachronistic customs and values rendered by dominant force. They still have no ability to seek education as they are deemed to be domestic servants and their duties are to care for babies, clean houses and perform all sorts of home-related chores. While Islam gives women equal dignity to men, including all sorts of rights granted to males, yet they spend their lives in Muslim culture without the rights stated in the Holy Quran and Shariah. Notwithstanding giving their freedoms, other societal inequalities reign in the community under which women are abused, ferociously handled and violently murdered.

On the contrary, there has been a continuous movement for women's rights in present day Pakistan even before it got independence. Educated women were active participants in the hectic political events of the time in East Bengal, Punjab, Sind and the North-West Frontier Province, and were keenly conscious of their privileges and entitlement. Such women were also active in the women's change movement, in particular the women's education movement. ${ }^{32}$ As Pakistan came into being, it had already educated, politically-conscious communities of women who then mobilized themselves to initiate a variety of successful women's movements. When Pakistan's new state came into being, its wealth were under the influence of deeply conservative patriarchal powers. The patriarchal forces dominated the political system, the process building in Pakistan led to women being increasingly marginalized. Women were still national identification markers, but the state's symbolic oppression of women contributed to, or was followed by, loss of their political rights. In Pakistan women have been disqualified, segregated and restricted to

\footnotetext{
${ }^{31}$ SCHEMAN, Reviewed Work 466-470.

${ }^{32}$ MumtaZ-SHAheED, Women of Pakistan 38-40.
} 
domestic spaces. Female education was abysmally poor, and was received entirely within the house's four walls. ${ }^{33}$

It should be stressed that Pakistan's founding father, Mohammad Ali Jinnah, believed in gender equality and saw women as equal citizens of Pakistan. ${ }^{34}$ He wanted women to play an active role in building a country on an equal footing. He once said: "No nation can rise to the height of glory unless their women are side by side with them (...). It is crime against humanity that our. There is no sanction anywhere for the deplorable condition in which our women have to live". ${ }^{35}$ In reality, however, "Pakistan was made only for the powerful and for the men. It was not made for weak and poor women like me. What are we worth and what is our status here? Nothing at all", as quoted by Basheeran Bibi, one of the numerous female victims of violence in Pakistan. ${ }^{36}$

Women became a key factor in the anti-colonial war as well as in the Pakistan revolution. ${ }^{37}$ The 'Pakistan' revolution opened up a new arena for political action for the Muslim women of the subcontinent in the 1940s. Pakistan developed on the basis of the principle of twonations theory and the association of religious identity with nationality. Although its establishment as an 'Islamic' country meant various things to different parts of society, the state's takeover into a coalition between the patriarchal and obscurantist powers guaranteed that the current political dispensation must impose patriarchy; gender inequities and the rejection of women's freedoms were therefore incorporated into the democratic framework. ${ }^{38}$

In the two decades following the creation of Pakistan, the policies discouraged religious orthodoxy and desisted from encouraging the obscurantist forces. Pakistan was declared an Islamic Republic much later, under the 1956 constitution, and the ulama were with an advisory role in the legislature. ${ }^{39}$ Maulana Madudi, ${ }^{40}$ representing the resurgence of political Islam in Pakistan, argued that voting should be extended to all adult males, but among women, educated among them should have voting rights. In the claims made by the Jama'at-i-Islami, it was clearly stated that public offices that could only be occupied by religious heads of state, and that qualified women were not permitted to take up any public office, were likely to come into conflict with men. ${ }^{41}$ Given the fact that women were very involved in the anti-struggle, when it came to their inclusion in the legislature, they were discriminated against. ${ }^{42}$ The newly formed state started to build facilities with the involvement of just a handful of people, and the orthodox Muslims were sometimes encouraged to either flee or participate in political action. ${ }^{43} \mathrm{~A}$ major challenge for women came in 1948, during the discussion on the budget session, when the first effort was made to protect women's economic rights. ${ }^{44}$

Pakistan's culture is no different from any other parochial and male dominated nation, where the prevailing patriarchal set-up scarcely allows the other half of the human populace a

\footnotetext{
${ }^{33}$ JALAL, The Convenience of Subservience 84-86.

34 JinNAH, Speeches and Statements 194.

35 BHATTACHARYA, Status of Women in Pakistan 179.

36 BHatTacharya, Status of Women in Pakistan 179.

${ }^{37}$ RousE, Women's Movement in Pakistan 30-37.

38 Rouse, Shifting Body Politics155.

${ }^{39}$ BhatTacharya, Status of Women in Pakistan 56.

${ }^{40}$ A recognized scholar of Islam and later head of the fundamentalist political party, the Jama'at-i-Islami.

${ }^{41}$ SYED, Pakistan: Islam, Politics and National Solidarity 68.

${ }^{42}$ Report of the Pakistan Commission on the Status of Women 1989, 113.

${ }^{43}$ KHAN, Women in Pakistan 9.

${ }^{44}$ BHATTACHARYA, Status of Women in Pakistan 55.
} 
chance to thrive and stand up for their own cause. Thus, such a pattern contributes to a community that basically gives women a derogatory role, Pakistan being the classical example. The country has made the International Politics, Benaziir Bhutto the first executive director of the Islamic state, and others such as: Sherry Rehman, Febmida Mirza, Hina Rabbani Khar. On the other side, there are instances of Mukhtaran Bibi, Tehmina Durrani and Malala Yusafzai. Such women are not limited to any single socio-economic group or to any rural urban divide. They have endured primarily for social and political causes at the hand of abusive offenders. ${ }^{45}$

The women in Pakistan witness a status of gender subordination based on their class and region. The simple reason behind this is the fact of uneven development in the socio-economic sectors and the impact of tribal and feudal systems on their lives. Several religious groups and ulama's who acquired political power during and after the period of Zia-ul-Haq advance and support the women subordination in Pakistan. Initially, the rape victims were not allowed to use DNA evidence in their cases to prove rape against the guilty party in Pakistan. However, with the passage of time, situation has improved in Pakistan with regards to the issues of the like. Now the women are allowed to prove their rape through DNA evidence, which is considered and admitted as conclusive proof in Pakistani courts too. As DNA test provides the courts with adequate means of identifying the accused / perpetrators with an increased degree of expertise, the DNA technology helps the courts in reaching a better conclusion whereby the real culprit could be convicted. Therefore, the Supreme Court of Pakistan in Salman Akram Raja vs. Government of Punjab $^{46}$ case enunciated new guidelines for the concerned authorities to compulsorily administer DNA tests and preserve DNA evidence in all rape cases in Pakistan.

However, with the passage of time, situation has improved in Pakistan with regards to the issues of the like. Now the women are allowed to prove their rape through DNA evidence, which is considered and admitted as conclusive proof in Pakistani courts too. Moreover, there are several examples of women who held esteemed and high positions in the government of Pakistan; leading among them is a twice elected prime-minister Benazir Bhutto. Additionally, the All Pakistan Ulama Council has recently released fatwas condemn honour killings. ${ }^{47}$ Some other improvements also surface as lady traffic wardens are employed in road traffic control measures and an attempt in being made to increase women percentage in police force as well. ${ }^{48}$ Despite these improvements, widespread domestic abuse, increased child marriages and rapes still remain a bitter truth of the Pakistani society.

\subsection{Historical background of status of women in Pakistan}

Historically speaking, Muslim reformers like Syed Abmad Khan advocated for women's right to education, prohibition of polygamy, and women empowerment by way of education. Jinnah was also known to possess positive outlook towards women's rights. His sister Fatimah Jinnah became a well known feminist struggling to alleviate socio-economic discriminations against women and she became a valiant force after independence for women rights. She also organized and

\footnotetext{
${ }^{45}$ BHATTACHARYA, Status of Women in Pakistan 56.

${ }^{46}$ See Salman Akram Raja vs. Government of Punjab [2013 SCMR 203], Constitution Petition No.38, $2^{\text {nd }}$ October

2012, https://districtcourtseast.gos.pk/pdfs/gbv.pdf.

${ }^{47}$ The Constitution of the Islamic Republic of Pakistan, http://www.pakistani.org/pakistan/constitution/.

${ }^{48}$ O' CONNOR, Gender and Women's Leadership 382.
} 
established several women's groups and feminist organizations to further her mission of empowering women in the nascent country, Pakistan.

According to Jinnah's own reflections, it is clear that majority of the Muslim women supported Pakistan movement in the 1940's and this movement was a success partly due to the un-yielding support of Muslim women from every corner, be such women a wife, mother, daughter etc. As soon as Pakistan came into being, the Muslim women were given the right to vote in 1947 and this right to vote was later confirmed during the national elections held in 1956 under the then constitution. Every constitution (1956, 1962 and 1973) in Pakistan provided for an express provision of seats reservation in Parliament for the women to give them the opportunity to participate in political process of the country.

The inclusion of ten separate women in the national and regional legislature was taken up as a big problem in 1953. The proposed Charter for Women's Equality was to be submitted to the Constitutional Assembly. Charter concerns such as parity of rank and opportunities, fair wages and the promise of freedom for Muslim women under Shariah. While the draft Charter was a significant effort at legislative security for women, it did not appear to obtain women's rights within the patriarchal political system as a revolutionary dream. The Constitution eventually enacted in 1956 approved the concept of separate female suffrage seats for women on the grounds of specific constituencies for women, thereby granting them equal voting privileges for general seats and reserved seats for women. ${ }^{49}$ Women's organizations persisted to struggle for their privileges. An event which became a cause of protest for women's rights organizations in 1955 was the second marriage of prime minister Mohammad Ali Boghra, which raised the issue of polygamy to prominence. ${ }^{50}$ The protests waged by women compelled the government to nominate a commission set up under the Supreme Court's Chief Justice, Justice Rashid, to review the current laws on polygamy, and to formulate laws on marriage, divorce, maintenance, etc. that would safeguard women's interests. ${ }^{51}$ The commission submitted its report in 1956 but was shelved under pressure from the orthodox clergy. ${ }^{52}$

Eventually, the suggestions of the committee were adopted by the military dictatorship of president Ayub Khan and were renamed 'Family Laws Ordinance 1961,.53 Ayub Khan introduced some changes to strengthen the status of women. During his strict and even despotic rule, attempts were introduced to encourage the schooling of women and their inclusion in government jobs and work. Aside from education, women were strongly promoted to take up careers such as media, research and civil service. ${ }^{54}$ Ayub Khan had a rather clear hostility to the conservative powers and kept them accountable for the destruction of the nation. Ayub Khans Family Ordinance was a significant effort to change family law in Pakistan. ${ }^{55}$ Many women in Pakistan were ignorant of their freedoms and were unaware of the benefits and entitlements they had under the constitution. And then, the Family Law Ordinance 1961 represented a significant move forward in the fight for women's rights in Pakistan. The women's movement in Pakistan

\footnotetext{
${ }^{49}$ Report of the Pakistan Commission on the Status of Women 1989, 113.

${ }^{50}$ MinaulT, The Extended Family 265-267.

${ }^{51}$ Report of the Pakistan Commission on the Status of Women 1989, 113.

52 KHAN, Women in Pakistan 268.

53 The Muslim Family Laws Ordinance 1961, http://punjablaws.gov.pk/laws/777a.html.

${ }^{54}$ KHAN, Women and State Laws and Policies in Pakistan, Reference no. 22.

${ }^{55}$ ENGINEER, Islam Gender Justice 96.
} 
has been influential not just in turning the ordinance into statute, but also in informing and educating women regarding their civil rights. ${ }^{56}$

The main features of the Family Laws Ordinance 1961 were: (1) Discourage polygamy and control divorce by allowing for specific protocols for both. (2) Second marriage was made conditional on the first wife's consent and on the approval of an informal council which was appointed locally. Second marriage without approval was subject to incarceration for one year and a penalty up to Rs 5,000. (3) In order to seek a divorce, the spouse was forced to give a formal note to the district council president, with a copy specifying particular grounds to his exwife. (4) For the first time a standard marriage contract form was issued and the registration of all marriages became obligatory. (5) The minimum marriage age for boys has been increased from 14 to 16 years, and from 18 to 21 years. (6) The ordinance provided for divorce by consent and delegated divorce for women.

While this legislation gave some protection to women, it still had several drawbacks. In addition, the legislation penalized women by forcing them to endure two years of non-support before applying for divorce on the grounds of lack of maintenance. The Family Law Ordinance was supposed to be widely opposed by conservative and oppressive movements, and several of them deemed it 'un-Islamic' and a breach of the rules of Islam. The reactionary forces were particularly shocked by the restrictions on polygamy and the encouragement of monogamous relations. They were often resentful of the limitations on the right to divorce for men. Nevertheless, because they saw the right to divorce as the sole privilege of men, they often opposed the extension or delegation of the right to divorce to women. Nevertheless, these rules were not universally enforced and were only marginally successful. In reality, their enforcement has been restricted, and existing practices and beliefs have also discouraged women from making full use of such rules. So far as women's rights are concerned, Ayub Khan's family laws are a milestone in Pakistan, even though his military government mercilessly crushed any dissension and political articulation of national, cultural and linguistic freedoms. In 1971, a transition of policy in 1969 put into force an independent and supposedly democratic administration. As a consequence of widespread popular opposition, the change from monarchy to democracy created an atmosphere of excitement and expectations of a new beginning. That was also the moment when there was a beginning of outspoken and self-defining feminists to attract focus with a fresh determination to women's problems. The new government, which tended to pull its decision makers from the left and democratic sectors of society, reacted predictably to this new ambience. ${ }^{57}$

In 1973, PpP government enacted a new constitution, which is still in force in the country. This constitution adopted the policy of gender equality in particular stating that "there shall be no discrimination on the basis of sex alone". It also provides additional protection in matters of marriage, family, mother and child along with a guarantee of "full participation of women in all spheres of national life ${ }^{358}$. The tenure of PpP government (1970-1977) is considered to be a period of liberal approach towards women and their rights. Women were allowed to work for any or all government services including the civil services, which was formerly barred to them. The PpP

\footnotetext{
${ }^{56}$ BhatTacharya, Status of Women in Pakistan 76.

${ }^{57}$ BHATtACHARYA, Status of Women in Pakistan 726- 733.

${ }^{58}$ The Constitution of Pakistan, 1973: Articles 25, 27, 32, 34, 35, http://www.pakistani.org/pakistan/constitution/.
} 
government also ensured a seat reservation of about $10 \%$ in the National Assembly and 5\% in the provincial assemblies, without putting any further limitation on contesting general seats. However, the government faced economical crisis due to East Pakistan separation in 1971 and could, therefore, not succeed well with the implementation of all such policies regarding women participation in legislative bodies. ${ }^{59}$ Also several judges upheld the implementation of Shariah laws, which were often misinterpreted and against the express provisions of the constitution calling for non-discrimination based on sex alone. ${ }^{60}$ Woman's problems gained much attention funded by the state in 1975, when Nusrat Bhutto attended the World Conference on Woman and a commission on women's status was established. ${ }^{61}$

In 1977, General Zia-ul-Haq overthrew the elected government of PpP and took charge of the country. The tenure of Zia's government is full of contradictions with regard to the status of women rights in Pakistan. On the brighter side, it is said that his regime took several steps to advance women rights by establishing a Women's Division, a Commission on Status of Women and a chapter on women in the Sixth Plan Development (1977-1986) for the very first time. Syeda Abida Hussain was made the chairperson for preparing this chapter with a group of twentyeight professional women. The main aim envisioned in this Plan was "to adopt an integrated approach to improve women's status" ${ }^{2}$ His government also doubled the quota for women's reserved seats in 1985, and appointed twenty women as members of the Majlis-e-Shoora (Federal Advisory Council). ${ }^{63}$

However, the darker side, which is a bitter truth, states that his Islamization process introduced discriminatory laws against women including the Hudood Ordinances ${ }^{64}$ and Qanun-eShahadat Order (Law of Evidence). ${ }^{65} \mathrm{He}$ prohibited women participation in sports and promulgated purdah. He also suspended the fundamental rights in entirety provided expressly in the 1973 Constitution, including the right to non-discrimination on the basis of sex. In reaction to Zia's controversial Hudood Ordinance, feminist struggle arose in the 1980's becoming the first real wave of women rights. This feminist struggle gave rise to women associations like the Women's Action Forum (WMA) and these forums condemned the unjust laws contained in the Hudood Ordinance raising awareness among the women in Pakistan. As these forums comprised of women from all spheres, they raised their voices against the government in media, through protests on streets, educational campaigns in schools/colleges and formulated famous slogans of 'Men, money, mullahs and military'.

Naturally, this feminist movement gained most attraction and appeal during the rule of female prime minister Benazir Bhutto, who served twice as the prime minister of Pakistan (19881990 and 1993-1996). ${ }^{6}$ During her tenure, the NGOs and other focus groups were granted considerable power to urge the government to make amends with regards to the status and rights of women. Glorified and celebrated as a daughter of East Benazir Bhutto was the first

\footnotetext{
${ }^{59}$ BENARD, Mapping the Issues 202-224.

${ }^{60}$ BETTENCOURT, Violence against women in Pakistan 3.

${ }^{61}$ Hussain, Military Rule, fundamentalism and the Women's Movement in Pakistan 29.

62 See Salman Akram Raja vs. Government of Punjab [2013 SCMR 203], Constitution Petition No.38, $2^{\text {nd }}$ October

2012, https://districtcourtseast.gos.pk/pdfs/gbv.pdf.

${ }^{63}$ BENARD, Mapping the Issues 213-224.

${ }^{64}$ UsMANI, The Islamization of Laws in Pakistan 287-304.

${ }^{65}$ MUSLIM, Islamization of Laws in Pakistan 265-276.

66 ALAVI, Pakistan: Women in a Changing Society 1328-1330.
} 
Muslim leader to become prime minister of Pakistan twice in 1988 and 1993, making a protracted and unflinching attempt to promote women by removing certain conservative and orthodox military acts and laws that hindered women's rights, setting up woman police stations, women's courts and women's Development Banks through which they were able to withdraw cheap loans for betterment of their condition. Unfortunately, the administrations were unable to complete their tenures and instead the presidents had the authority to disband the legislatures unevenly under article 58(2)(b) so she may not be able to make pro-women laws in order to improve the social status of women. Moreover, several women in Pakistan still have to undergo social, religious, economic and political hurdles, which prevent them from exercising their political rights as voters, candidates and election administrators. With the turmoil in Afghanistan in early 2000s, the Taliban took refuge within the territory of Pakistan. These Talibans implemented strict Shariah codes within the territories they acquired control upon, thus denying women their due rights and freedom guaranteed under the constitution of Pakistan. This tight control of Talibans on women affected the existing educational lack in Pakistan, as they did not allow women to attend schools, rolling Pakistan to second place in the highest number of out-of-school children in the world according to the UNESCO report of 2014.

To add to this dismal situation, prime minister Nawaz Sharif took office in 1997who came into power gaining strong support from Islamic parties and mullahs. In the first two terms, the Nawaz government made some attempt to strengthen women by introducing the 15th amendment, but it was largely focused on the Islamization introduced by Zia-ul-Haq, which was accepted by the National Assembly, but rejected by social movements, women's rights NGOs and the opposition, who simply sought to abolish budood laws against women. The state has launched a 10-year strategy detailing 16 of the goals laid forth in it for strengthening women1s status and a revised 'Human Development and Poverty Reduction Strategy" ${ }^{67}$ targeted at reducing women's deprivation. All mentioned programs could not run in long since due to short period of governments' terms comprised on half period. ${ }^{6}{ }^{6}$ Consequently, women found themselves caught in losing battle against the conservative and religious political rivals. ${ }^{69}$ During Nawaz Sharifs rule, the Council of Islamic Ideology (CII) also made recommendation to make burqa compulsory which led to an increased toll of honour killings. Soon, the women realized that their struggles for empowerment were not all in vain.

They again received momentum during the regime of General Pervaiz Musharraf, who rallied for women empowerment and encouraged them to participate in media, sports and other socio-political activities. It is hard to claim because Pakistan's historical past has mainly consisted of dictatorial governments by enforcing martial laws, which is why democratic standards have not entered society and citizens lack political knowledge. General Musharraf enforced the last martial law on 12 October 1999 by overthrowing the second term of Nawaz. Sharifs administration, but he took several important measures to motivate women and boost their social standing when he created the Ministry of Women's Development as an autonomous ministry in 2004. This movement to empower women is still in force, although to a lesser degree than before, along with efforts of WMA, who has successfully been able to get through

\footnotetext{
${ }^{67}$ BHATtacharya, Status of Women in Pakistan 179.

${ }^{68}$ Mustafa - Ayazul Qasmi, An Analysis of Women Right's in Pakistan 147-159.

${ }^{69}$ BENARD, Mapping the Issues 234.
} 
women-friendly bills, for example the Criminal Law Amendment Act (2004), the Anti-Sexual Harassment Bill, the Criminal Acid Act, Protection of Women Act, Status of Women Bill and sundry regulations condemning honour killings and other vices faced by women in Pakistani society.

Moreover, president Asif Ali Zardari (2008-2013) is known to be influential in protecting women and has helped them to get rid of social ills against women, enacting such laws and measures, such as the $18^{\text {th }}$ amendment, deemed a landmark in the history of the country where women's affairs ministry has been handed over to the provinces. The government has also passed the National Commission Act on Human Rights, particularly for women in 2012. Several schemes have also been launched, such as the Benazir Income Support Program under this program; one million women are providing economic assistance and similarly the Women Detention and Distress Fund Act granting unique relief and financial assistance. In addition, twenty-six Benazir Bhutto Shaheed Centres were also established in various districts to provide urgent assistance. During the rule of Ppp under president Asif Ali Zardari has raised the number of women participation on political forum by appointing women on esteemed positions like the speaker of Parliament Dr. Fehmida Mirza, foreign minister Hina Rabbani Khar, media advisor Sherry Rebman and others who held prestigious positions within the government administration. Zardari also signed the bill on 'Protection against Harassment of Women at Workplace Bill 2009' that was adopted by the Parliament in $2010 .^{70}$ In addition, he also signed two other bills in 2012 aiming at criminalizing the traditional practices of vani (custom), watta-satta marriage (exchange marriage) or swara marriage (marriage as retribution) to the Quran, acid throwing etc. ${ }^{71}$ The new government has recognized that by overlooking $52 \%$ of the population of the country comprising of women, cultural, political and social stability cannot be accomplished since they are the major capital of Pakistan. The Government has therefore formed a Convention on the Abolition of All Kinds of Violence Against Women, so that they may engage in any sphere of life. Similarly, the government has embarked on a Prime Minister's Youth Loan Scheme to support young people in the country in general and women in particular to motivate them and then to enhance output levels in all sectors, such that the country's GDP can also be increased. Along with this, several other legislation were introduced to emancipate women and hamper the barbaric actions committed at regional level by the second gender. As the Punjab Provincial Assembly passed an act offering security for women, allowing them to detain their husbands and keep them out of the house for 48 hours. Therefore, like the Sindh Assembly, the rule against the men who are performing a barbaric act of acid throwing at the faces of their females is insane.

However, like the Nawaz, government during its first tenure, the current government of Pakistan Tehrik-e-Insaf (PTI) party also seems a bit conservative and restrictive. The current prime minister, Imran Khan seems to favour Islamic ideals which might ultimately affect the status of Pakistani women in future. While all the listed laws are enshrined to emancipate, empower and strengthen their position in all walks of life, certain barbaric, outmoded and anachronistic rituals, norms, practices and social evils prevail in this society. Currently Pakistan's women are split into two groups as urban as well as rural. Urban women's lives are better than rural women as they are

\footnotetext{
${ }^{70}$ NoreEn - Musarrat, Protection of women rights through legal reforms in Pakistan 128-129.

${ }^{71}$ Staff Report, President signs two women's rights bills into law, https://www.pakistantoday.com.pk/2011/12/23/president-signs-two-women $\%$ E2 $\% 80 \% 99$ s-rights-bills-into-law/.
} 
more encouraged and not restricted to house walls and engage in any field of life such as engineering, medical, employment, politics, international services and so on. Yet in rural areas, women's lives are very congested, lonely, dirty and wretched for backwardness and illiteracy, women face the evils of anti-woman and gender abuse prevalent in society in the form of karokari (Honor killing), vani, honour killings, forced marriages, child marriages, marriages with Quran, burning brides and acid attacks. According to the 2015/16 annual study by Women Amnesty International, 8,539 incidents of violence against women were reported, of which 1,575 were homicides, 827 rapes, 610 domestic abuse, 705 honour killings and 44 acid attacks. ${ }^{72}$

\subsection{Status of women under Shariah law}

When we analyse the pre-Islamic and post-Islamic socio-cultural and political status of women, we can see a steady rise in their role. Islam as a faith presented women with elevated dignity and resources to develop them as a significant part of society. Women in Arabia in periods of poverty, before Islam (Jabiliyah) ${ }^{73}$ were subjugated either to their families or their spouses. At that time, when war was ongoing, women were also taken as captives. They were usually regarded as bondmaids by the enemy and held in contempt. Although they were kindly treated by their captors, yet they were always embarrassed, and stripped of their own men and homeland. Women had little control or influence over matters pertaining to their well-being and were exempt from any significant involvement in their respective social and political relations. One of the social reasons for such an attitude was that there were often inter-tribal blood feuds in preIslamic times, demanding that male members defend their tribes. Men were therefore much more in demand than women. In such an anarchic age, Islam has, on theory, introduced the concept of freedom and justice for women in the harsh desert of Arabia.

With one move, Islam removed the stereotype of a woman that she was the everlasting seducer and tempter of a man, and that she should be honest and sinless to her man/husband. Islam presents women with fair rights and has an individual identity that cannot be subjugated. The Holy Quran has disclosed humanity's roots and presented men and women as compatible elements of a society worthy of sustaining human race's life together. The book (Holy Quran) addresses both men and women in same manner i.e. AlInsan, Al Bashar and Al momin. Islam provides women with status or position, financing, political rights, etc. Nonetheless, the Qimwama of husbands over their spouses is one of these examples. A husband is Qawwam that is to claim he respects his wife's needs. The Quran's mention is made that it is the man's duty to support his wife and family behind the granting of Qimwama right to husbands over their wives. ${ }^{74}$

Most notably, Islam not only grants women social freedoms, but also equal civil privileges. She will purchase her own money and land, market and make a living. In Islam the woman is constitutionally equal and is autonomous of her family, partner, or brother's responsibilities. Furthermore, Islam has given women the freedom to inherit both moving and immovable property. After the death of male family members (father, husband and brother), she

\footnotetext{
${ }^{72}$ Mustafa - Ayazul QASMi, An Analysis of Women Right's in Pakistan 152-153.

${ }^{73}$ Sulaimani, The Changing Position of Women in Arabia under Islam During the Early Seventh Century 5-6.

${ }^{74}$ The Holy Quran, Surah An-Nisa 4, Verse 34.
} 
still bears the right to inherit land. ${ }^{75}$ Women earn compensation for raising children as well as their living expenses from their husbands even in the case of divorce. ${ }^{76}$ Sadly, this dimension of equality has been substituted over a span of time by gender segregation and injustice, thus degrading to the extreme level of violence in Pakistan. The proliferation of customary rules became more apparent as Islam spread far and large. The very nature of Islam has also been corrupted, which is clear in Pakistan. Throughout the absence of freedom for women, abuse was the traditional norm of the society.

While Pakistan is an Islamic state, it derives its definition from customs and cultural norms in terms of women's rights. The existence of parallel justice system such as Jirga and Panchayat is generally apathetic to women and their grievances and therefore the existence of both legal and religious safeguards and measures does not permeate the structure of society. Even the uncertainty factor prohibits women from claiming their freedoms. Such bodies administer or enforce penalties on those who claim their human rights against the specified tribal or group norms. Such tribal justice system is recognized in different places by constitutional law (including Federally Administered Tribal Areas (FATA) and Provincially Administrated Tribal Areas (PATA), but it is also unlawfully in Pakistan. Throughout these places, regular judicial tribunals do not have authority over a Jirga decision and there are instances where human rights covered by constitutional law are infringed. The Jirgas function against women's rights and actions is often focused on stark bias and bigotry towards women centred on their cultural and religious stereotyping of women's position.

How and why did the role of women decrease in Islamic society? In medieval cultural practice the solution can lie, as most early jurists come from urban Arab community and culture of the $7^{\text {th }}$ century. The Arab customary laws (habits/adaat) were a component of the Shariah, unfortunately, most Muslims believe that even these adaat too are divine and binding because of a lack of proper knowledge and understanding, and hence Quranic injunctions on gender justice have been diluted. And secondly, the fabrication of hadith (sayings of the Prophet) also caused discrimination. The Quranic injunctions in favor of women were not appropriate in a patriarchal community, as they questioned the supremacy of men and considered women equal to men.

Therefore, it may be assumed that the issue is partly cultural and partly religious. Unfortunately, Islamic zealots seek to excuse the prevailing cultural and social misdeeds on the grounds of Islam. Sadly, at the individual level, women themselves are still not informed of the privileges enshrined in Islam. Islam finds all men and women fairly divine and gives equitable civil rights. Both genders have common and similar roles to do, such as prayer, ceremonies, fasting, etc. According to Islam, moral supremacy is focused exclusively on modesty and not on gender basis. ${ }^{77}$ Women who have a career or employment outside their home are not restricted by Islam. ${ }^{78}$ But in fact, women are more acquainted with the concocted version, as proclaimed with a certain bent of mind by religious leaders. This passive personality is triggered by a serious case of denial or could be lihaaz (respect) engrained in their psyche by family and surroundings. This

\footnotetext{
${ }^{75}$ The Holy Quran, Surah An-Nisa 4, Verses 7, 11.

${ }^{76}$ FAROOQI, Emancipation of Women of Islam 21.

77 The Holy Quran, Surah An-Noor 24, Verses 30, 31.

${ }^{78}$ HAKIM - AZIZ, Socio-cultural, Religious, and Political Aspects of the Status of Women in Pakistan 727-746.
} 
docility is certainly evident in Pakistan as females try to reconcile with abuse and within them there is a clear sense of remorse.

As far as women's rights are concerned, while Shariah provides such basic privileges for women, it does not equate them with men. Therefore, oppression dependent on religion is a component of Shariah. Many Muslim nations, following Shariah rules like Pakistan, position women in lower rank by enforcing gender discrimination, confining them to their houses, forcing them to wear the hijab and refusing them the right to hold high public office. In reality, the practice of Shariah does not look favourably upon the jobs of women. Also, a woman is generally entitled to inherit only half the share of a man of the same degree of relationship to the deceased in Pakistan and several Muslim countries following Shariah law. A man is allowed to marry up to four women at once, whereas women can only have one partner. Whereas the husband may divorce his wife at his choice, a woman may request a judicial divorce before a male judge without justification for doing so, and is expected to provide clear grounds for divorce. A parent, partner, sibling, uncle or even son can have jurisdiction over a woman whose right to a fair care is subject to the authority of that individual. For all commercial transactions, the Qur'an specifically requires two male witnesses, or one male and two female witnesses. The evidence of two women equals that of one man, in addition to the fact that the compensation for murdering a woman unlawfully is also half that for killing a man. ${ }^{79}$

The Convention on the Elimination of All Forms of Discrimination Against Women $(\mathrm{CEDAW})^{80}$ has only been accepted by a limited number of Islamic nations, even with significant reservations. To clarify, reservations usually indicate that the state does not find itself bound by the terms of those clauses "unless they clash with Shariah law centred on Holy Qur'an and Sunnah". Indeed, as regards Article 2 of the convention, which obliges parties to take substantive steps to counter prejudice, reservations indicate that the State is unable to cooperate with the content or substance of the convention. Likewise, the ratifying Muslim states have reserved Article 16 of the convention, which obliges the parties to "take all necessary steps to eradicate discrimination against women in all matters relating to marriage and family relations", and mentions each marital and family right separately, allowing the parties to give women equality in those relationships, including marriage. Such objections evoke Shariah limitations on the freedom of the wife to divorce by rendering it dependent on a judge's decision, while in the husband's situation there is no such limitation.

\subsection{Status of women under constitutional and other statutory laws}

The status of women in Pakistan is a complicated phenomenon due to a multi-cultural ethnicity. Women's condition in Pakistan is lamentable owing to non-implementation of the pro-women legislation. This barricades offer a blank field for abuse, injustice, racial discrimination, and oppression towards women that has become this society's fundamental principle and strong conviction. Many consequences from qualitative and quantitative data research clearly illustrate the importance of various different aspects and enormous obstructions in the path of women's security and protection laws. These as the intrinsic obstacles, including: the prevailing and

\footnotetext{
${ }^{79}$ NANDA, Islam and International Human Rights Law 327-731.

${ }^{80}$ WEISS, Interpreting Islam and Women's Rights 87.
} 
mischievous conduct of men toward women, the acknowledgment of the reality that women are in the hands of men, and the superiority and prestige gained by men and counter to this societal arrogance and disrespect towards women. Simultaneously extrinsic problems such as: societal norms on the treatment of women, impotence of mass media, hegemony in the social climate, systemic bigotry of law enforcement agencies, heritage of socio-political values, illiteracy, legal illiteracy, fear of notoriety among women, incapacity of the justice system, denial of justice, renunciation of judicial changes, cynical position of the police and stewardship. ${ }^{81}$

With regard to status of women, Pakistan has made continuous efforts towards introducing the laws relating to the protection and security of women since 1947. There was minor legal peculiarity between the men's and women's privileges they possessed at the time of independence. According to section 8 to 28 of the constitution of Pakistan 1973, the basic rights of all the people in Pakistan are complied with in all respects without prejudice, ethnic diversity and gender. On the other hand, there were struggles made to stop the continuous practice of violence against women through enactment of numerous laws e.g. Muslim personal aw of Shariah, Muslim Family Law Ordinance, Hudood Ordinance, Women Protection Bill, Sexual Harassment Bill, Prevention of Anti- Women Practices Bill, Acid Control and Acid Crime Prevention Bill, Child Marriages Act.

In addition, Pakistan has been a partner to numerous foreign and regional conventions for the security and equitable rights of women. Pakistan is a signatory to the International Population and Development Conference (ICPD), the Beijing Action Plan and the United Nations) $)^{82}$ Pakistan acceded to the Convention named 'Elimination of All Forms of Discrimination Against Women (CEDAW) in 1996, issuing a declaration on the Convention and making a reservation on Article 29. Pakistan has also committed itself to "pursue by all appropriate means and without delay a policy of eliminating discrimination against women". It is therefore obliged to remove "any distinction, exclusion or restriction made on the basis of sex which has the purpose of impairing or nullifying the recognition, enjoyment or exercise by women on the basis of equality between men and women, of buman rights and fundamental freedoms". 83

Unfortunately, all these pro-women laws grant and protect the women rights theoretically, but not practically. These legislations are nothing more than a piece of paper. To add to dismay, the State's radicalization has deprived the country of the environment necessary for the actual implementation of these different laws and, in turn, for the protection of the female population. Most of such laws remain on paper, while the regulatory machinery of the country is, on the one side, restricted to coping with a deluge of extremism and enveloping violence, yet, on the other, oblivious to the plight of women in a culture that is parochial yet profoundly dedicated to a theological and political agenda that opposes and tries to remove women from the mainstream..$^{84}$

Many Islamic fundamentalists are against any change regarding women's rights that can undermine male domination with regards to family and society. Their goals are to setup special curriculum to train girls for their role as housewives, to restrict their access to political life, remove them from the legal profession, and to impose a rigid dress code. Despite these

\footnotetext{
${ }^{81}$ Moosvi, Status of Women 1850-1990.

82 National Commission on the Status of Women Islamabad 11.

${ }^{83}$ BrightMAN, Rights, Women, and the State of Pakistan 334-351.

${ }^{84}$ BhatTACHARYA, Status of Women in Pakistan 56.
} 
inequalities between men and women, for many of these women freedom of expression and equality do not seem meaningful goals to obtain. The majority of them see the Western culture as a danger for their native culture, bringing with it the disintegration of families and social breakdown due to this mullah mind-set. ${ }^{85}$

A thorough examination of the realistic implications of implementing the rights of women under Shariah law in Pakistani society indicates that the rules on several accounts are severely breached, in modern times. There are people who, consciously or unknowingly, deviate from the teachings and guidelines of Islam in this regard. Pakistan is an Islamic republic; any rule and regulation in the country is focused on Islamic law. Around the same period, moreover, there are rituals and practices against Islamic rules that are widely observed. Cultural traditions in Pakistan do not require women to enjoy their civil and religious freedoms, guaranteed by law and supported by Islam. ${ }^{86}$

However, over the times, women have been provided with legal rights and safeguards in Pakistan in the form of constitution and legal instruments. A legal right has been defined in Black's Law Dictionary 2 as: "a right created or recognized by law". Following are the different categories of legal rights for women in Pakistan provided in length in the constitution and respective statutes: (1) rights provided to women under constitutional law; (2) rights provided to women under criminal law; (3) rights provided to women under civil law, (4) rights provided to women under family law.

\section{Conclusion}

As mentioned above, Pakistan has come into being with the pre-text of Islam, but it is quite disheartening to see that religious and Quranic values are often ignored and twisted, particularly as regards the role of women. Incidentally, in Pakistani society, the social evils that Prophet Mubammad fought against for the whole of his life are deeply rooted and the so-called guardians of the faith take them as normal routine of 'punishing' and ostracizing the women. The modern culture of defending abuse and oppression in the name of Islam must be discouraged. In Pakistan's background, religion has not been able to eradicate centuries old un-Islamic and even barbaric social evils and this has been a cause of critical concern. The mal-practices of illiterates or Jahiliyyah are currently ongoing in Pakistan. Worse still, religious clerics and preachers are sanctifying and propagating 'customary laws' in the name of Islam. Additionally, mass ignorance and the element of fear also causes brutality against women, as female are wrongly told from childhood to 'not question the scriptures'. They are conditioned to be ignorant not only about legal rights but, also about the 'true principles of Islam'.

Furthermore, this chapter addresses the general and contractual status of women in Pakistan, who usually experience gender subordination based on their class and region. The simple reason behind this is the fact of uneven development in the socio-economic sectors and the impact of tribal and feudal systems on their lives. Several religious groups and ulamas who acquired political power during and after the period of Zia-ul-Haq advance and support the women subordination in Pakistan. Therefore, women's rights are human rights that can be

\footnotetext{
${ }^{85}$ OFFEN, Women in the Western World 145-151.

${ }^{86}$ BhatTacharya, Status of Women in Pakistan 56.
} 
secured only if the Pakistani society is free from gender-based violence and addresses women's position as women are not only mothers, daughters, sisters and wives, but also human beings. In the light of the above discussion about women's status in Pakistan, improved legislation seems to be an important tool in bringing the status of women in the context of social, economic and political aspects. For that purpose, it can be seen that the Supreme Court of Pakistan has been continuously supporting and securing women's rights within the constitutional framework by following a progressive interpretation of Shariah law. However, besides this progressive attitude of the courts of Pakistan towards the status and rights of women, there is still much work left to do in this regard. There is a dire need to find a common core between the rulings/laws of both the legal systems in order to find solutions to the existing laws of inequality and subordination of women in Pakistan.

Hence, it is important to organize regular training and awareness programs periodically to make women aware of their rights and empower them to exercise only just demands. In addition, the present laws need to be revised and modified. More specifically, in a dogmatic society in Pakistan, proper law enforcement is very critical to providing women with a safe and secure environment to prosper themselves. And there is a need to establish a national and district level women's legal assistance centre.

Moreover, while discussing women's status in Pakistan, it becomes evident that Pakistan is tossing between the traditional Shariah law and modern common law system. This modern legal system has been forced on Pakistan much like every other post-colonial country, but the culture has not fully changed from inside. Therefore, the constant tussle between the two is taking its toll on the female population, resulting in women oppression. To sum-up, Pakistan needs to address the issue of women's status with acumen by reducing the existing gulf between theory and practice regarding empowerment of women. The government of Pakistan must bridge this gap by taking proficient steps to empower the women who have become a sign of oppression and disparity not only domestically but also internationally. It should provide the women with opportunities to compete men on an equal platform, in order to acquire parallel status.

\section{Bibliography and sources}

Alavi, Hamza: Pakistan: Women in a Changing Society. Economic and Political Weekly, Volume 23, 26/1988, 1328-1330

BALOUCH, Akhtar: Muhammad Bin Qasim: Predator or preacher? DAWNN News 2014 https://www.dawn.com/news/1098562

BETTENCOURT, Alice: Violence against women in Pakistan. Litigation Report 2000, 3

BHATTACHARYA, Sanchita: Status of Women in Pakistan. Journal of the Research Society of Pakistan, Volume 51, 1/2014, 179

Brightman, Sara: Rights, Women, and the State of Pakistan. Contemporary Justice Review, Volume 18, 3/2015, 334-335

BROOKS-POLLOCK, Tom: The countries where a majority of Muslims want to live under Shariah law.

The Independent 2015

https://www.independent.co.uk/news/world/the-countries-where-a-majority-of-muslims-want-to-live-und under-sharia-law-a6773666.html

DhuliPALA, Venkat: Creating a New Medina: State Power, Islam, and the Quest for Pakistan in Late Colonial North 
India. Cambridge 2015

Diamantides, Marinos - Gearey, Adam: Islam, Law and Identity. Routledge 2011

EngINeER, Asghar Ali: Islam Gender Justice: Muslim Gender Discrimination. Gyan Publishing House 2013

FAROOQI, Hafiz Abdullah: Emancipation of Women of Islam. The Pakistan Review, Volume 13, 5/1956, 21

GROTE, Rainer: Constitutionalism in Islamic Countries: Between Upheaval and Continuity. Oxford 2012

HAkim, Abdul -AzIZ, Azra: Socio-cultural, Religious, and Political Aspects of the Status of Women in Pakistan.

The Pakistan Development Review, Volume 37, 4/1998, 727-746

HAQQANI, Hussain: Pakistan: Between Mosque and Military. Carnegie Endowment 2010, 18\&395

Human Rights Watch: Double Jeopardy: Police Abuse of Women in Pakistan1992

Hussain, Neelam: Military Rule, fundamentalism and the Women's Movement in Pakistan. In: KHAN, Nighat Said:

Up Against the State. ASR Publications 2004, 19\&29

IIJIMA, Masako: Islamic Police Tighten Grip on Indonesia's Aceh. Reuters

2010 https://www.reuters.com/article/us-indonesia-aceh-police-idUSTRE60D07420100114

IQBAL, Khurshid: The Right to Development in International Law: The Case of Pakistan. Routledge 2009

JONES, Owen Bennett: Pakistan: Eye of the storm. Yale University Press 2002

HeNG, Michael - LIEW, Ten Chin: State and Secularism: Perspectives from Asia. World Scientific 2010

KEPEL, Gilles: Jihad: The Trail of Political Islam. I.B.Tauris 2002

KHAN, Sher Ali: Global connections: The crackdown on HizbutTahrir intensifies. Herald 2016 https://herald.dawn.com/news/1153325/global-connections-the-crackdown-on-hizbut-tahrir-intensifies

KHAN, Sana. Women and State Laws and Policies in Pakistan: The Early Phase, 1947-77. Proceedings of the Indian History Congress, Volume 74, 5/2013, 726-733

KHAN, Nighat Said: Women in Pakistan: A New Era?. Change International Report 1985, 9

LAPIDUS, Ira Marvin: A history of Islamic societies. Cambridge 2002

LAPIDUS, Ira: The Cambridge Illustrated History of the Islamic World. Cambridge 1996

LONG, Roger D. - Singh, Gurharpal - SAMAD, Yunas -TALBOT, Ian: State and Nation-Building in Pakistan: Beyond Islam and Security. Routledge 2015

MAYER, Ann Elizabeth: Law. Modern Legal Reform. In: EsPOsITO, John L.: The Oxford Encyclopedia of the Islamic World. Oxford 2009, 381-389

Minault, Gail: The Extended Family. Chanakya Publications 1981

Moosvi, Shireen: Status of Women: India and Pakistan. UnesCo History of Civilization of Central Asia, Volume 6, 1/2005, 1850-1990

MuneER, Sania: Pro-women Laws in Pakistan: Challenges towards Implementation. Pakistan Vision, Volume 18, 2/2018, 86-101, https://www.researchgate.net/publication/324039364

Muslim, Abdul Ghafur: Islamization of Laws in Pakistan: Problems and Prospects. Islamic Studies, Volume 26, 3/1987, 265-276

Mustafa, Ghulam - Ayaz ul Qasmi, Hafiz: An Analysis of Women Right's in Pakistan: Theory and Practice. Journal of Historical Studies, Volume 3, 1/2017, 147-159

NANDA, Ved P. Islam and International Human Rights Law: Selected Aspects. American Society of International Law, Volume 87, 3/1993, 327-331

National Commission on the Status of Women Islamabad: Institutional Strengthening of Ncsw Support to Implementation of GRAPS: Study to Assess Implementation Status of Women Protection Act 2006 http://www.ncsw.gov.pk/previewpublication/4?_cf_chl_jschl_tk_=f3b12df61875b61436bb52bd1bfd78 b80f51c5cc-1597744215-0-

AS8ebg7SWn_7RcEL3wnUKijvtCAcrneQGjd3rC67BrTZGFMAkkoCROBFDK5qfk6SdcgY3w19jwliYYb RzpC-3fjFq2WsQhGFSzByMPDAlM6uqyYa-iDjAOYdn0796cziedzI9AhQVHaTWVK-5bLZbQQXrAHcSUOFKzQCZXC_jvccUaZTwdBEuZXNHxYYVV4d2kmk2iXAIl8elxNEN5hXbX2xiNKM CGumykX12enacvCIqCtLYqnRblV7J9nQnJ7_gQG4H85E1w8S6KxCq0-ydBhkT_AxdAfgEI52o8K15sr

NoreEn, Naveeda - MusArRAT, Razia: Protection of women rights through legal reforms in Pakistan. Journal of Public Administration and Governance, Volume 3, 4/2013, 128-129.

O’CONNOR, Karen: Gender and Women's Leadership: A Reference Handbook. SAGE Publicating 2010

OFFEN, Karen: Women in the Western World. Journal of Women's History, Volume 7, 2/1995, 145-151

Отто, Jan Michiel: Shariah Incorporated: A Comparative Overview of the Legal Systems of Twelve Muslim Present 
Countries in Past and Present. Leiden 2009

OтTO, Jan Michiel: Shariah and National Law in Muslim Countries: Tensions and Opportunities for Dutch and EU Foreign Policy. Amsterdam 2008

PAL, Mariam S.: Women in Pakistan: Country Briefing Paper. Asian Development Bank 2000 https://www.adb.org/sites/default/files/institutional-document/32562/women-pakistan.pdf

PARACHA, Nadeem F.: The first Pakistani? DAWN News 2015, https://www.dawn.com/news/1175127

RAFI, Shazia: A case for Gandhara. DAwN News 2015, https://www.dawn.com/news/1164469

Reuters: Sherry Rehman appointed Pakistan's ambassador to US. DAWN News 2011 https://www.dawn.com/news/675333/sherry-rehman-appointed-pakistans-ambassador-to-us

SAIGOL, Rubina: What is the most blatant lie taught through Pakistan textbooks? Herald 2014 https://www.dawn.com/news/1125484

SAIGOL, Rubina: Pakistan's Long March. Development and Cooperation, Volume 36, 5/2009, 208-210

Salman Akram Raja v Government of Punjab: 2013 SCMR 203, Constitution Petition No.38, 2nd October 2012, https://districtcourtseast.gos.pk/pdfs/gbv.pdf

Staff Report: President signs two women's rights bills into law. Pakistan Today 2011 https://www.pakistantoday.com.pk/2011/12/23/president-signs-two-women $\%$ E2\%80\%99s-rights-billsinto-law/

STAHnKe, Tad - BlitT, Robert C.: The Religion-State Relationship and the Right to Freedom of Religion or Belief: A Comparative Textual Analysis of the Constitutions of Predominantly Muslim Countries. Georgetown Journal of International Law, Volume 36, 4/2005, 13-19

STEWART, Devin J.: Shari'a. In: Böwering, Gerhard- Crone, Patricia: The Princeton Encyclopedia of Islamic Political Thought. Princeton University Press 2013

Sulaimani, Faryal Abbas Abdullah: The Changing Position of Women in Arabia under Islam During the Early Seventh Century. University of Salford 1986

SYED, Anwar: Pakistan: Islam, Politics and National Solidarity. Praeger 1982

The Constitution of the Islamic Republic of Pakistan 2010, http://www.pakistani.org/pakistan/constitution/

Usmani, T.: The Islamization of Laws in Pakistan: The Case of Hudood Ordinances. The Muslim World April, Volume 96, 2/2006, 287-304

WEISS, A. M.: Interpreting Islam and Women's Rights: Implementing CEDAW in Pakistan. International Sociology, Volume 18, 3/2003, 587

Gilmartin, David: Stanley Wolpert. Zulfi Bhutto of Pakistan: His Life and Times. Oxford 1993, 1743-1744

WynBRANDT, James: A Brief History of Pakistan. Facts on File, Inc. 2009, 216-217 